\title{
De danske husholdninger og stagnationspolitik
}

Mogens Ove Madsen, lektor, kand.samf.øk., Institut for Økonomi \& Ledelse, MaMTEP Aalborg Universitet.

Mikael Randrup Byrialsen, Adjunkt, cand. oecon, ph.d., Institut for Økonomi \& Ledelse, MaMTEP, Aalborg Universitet.

Den danske økonomi er havnet $\mathrm{i}$ en tilstand af stagnation uden økonomisk vækst. I denne artikel undersøges årsagerne til denne situation på baggrund af en analyse inspireret af den Keynesianske økonom Josef Steindl med særligt fokus på de danske husholdningers adfærd og den manglende økonomiske politik. I artiklen fremføres, at mens husholdningernes låntagning inden krisen bidrog til den økonomiske vækst, hæmmer resultatet af denne låntagning den nuværende vækst i den danske økonomi.

Introduktion ${ }^{1}$

"This policy of stagnation is likely to continue, since governments are preoccupied with inflation and the public debt. Budget deficits can only disappear if private investment soars again. This is unlikely in view of excess capacity, which would only disappear if there were fiscal expansion.” (Steindl 1979, 9)

Selvom ovenstående citat fra Steindl er mere end 30 år gammelt, så illustrerer det på bedste vis den situation, som den danske økonomi har befundet sig i siden 2010. De høje vækstrater i den danske BNP op gennem 00'erne blev i 2008-2009 afløst af negative vækstrater i kølvandet på den økonomiske krise. Modsat væksten i en række andre lande, er væksten i den danske økonomi dog ikke kommet i gang igen, og vækstraten var således negativ i såvel 2012 som 2013. At den danske økonomi er fanget $i$ en lavkonjunktur kan ligeledes illustreres ved, at den reale BNP i Danmark stadig er på et

\footnotetext{
${ }^{1}$ Vi skal takke Finn Olesen samt to anonyme bedømmere for kommentarer til en tidligere version af nærværende papir.
} 
lavere niveau end i 2008. Sammenlignes udviklingen i Danmark med udviklingen i EU og USA, kan det ses, at den amerikanske økonomi hurtigt nåede sit niveau før krisen, mens udviklingen i EU-landene ligner den danske udvikling mere - dog på et niveau tættere på niveauet før krisen.

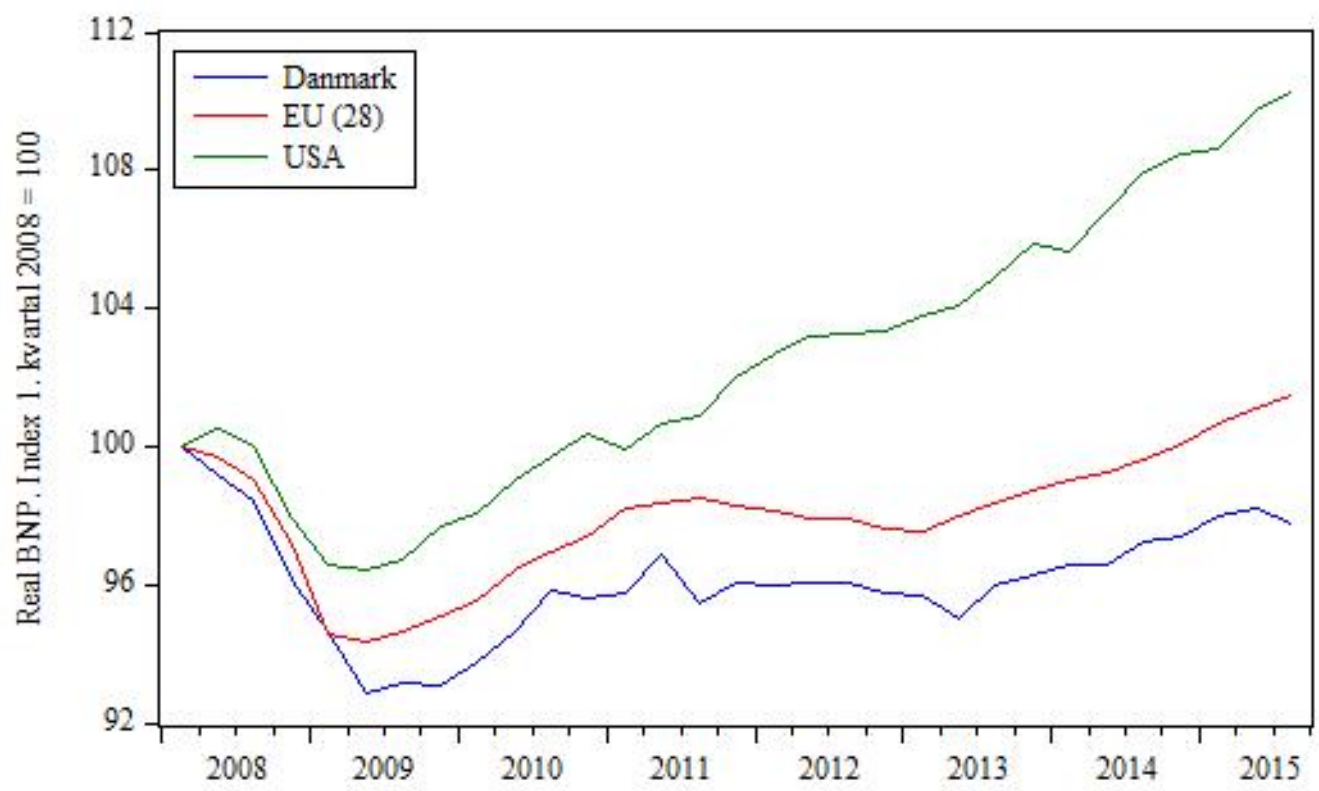

Anm: Det kvartalsvise data er opgjort i national valuta, kædede var dier og sæs onjusteret. Kilde: OECD og Danmarks Statistik

Figur 1. Udviklingen i real BNP i Danmark, USA og EU(28)

Som det illustreres af ovenstående figur, er den danske økonomi, som en del andre vestlige lande havnet $\mathrm{i}$ en situation med lave eller negative vækstrater - stagnation. Årsagerne til denne stagnation har været diskuteret bredt.

Diskussionen om stagnation er dog ikke ny, men i stedet en tilbagevendende diskussion. Hos fx Paul Krugman trækkes diskussionen direkte tilbage til Alvin Hansens anvendelse af secular stagnation fra 1939. I Hansens optik var årsagen demografisk, og den lave befolkningstilvækst fik skylden for den lave investeringsefterspørgsel (Hansen 1939). Hos Krugman er årsagen, at den nuværende vækst er lavere end den potentielle vækst samtidig med, at den naturlige realrente er negativ, hvorfor pengepolitik ikke kan anvendes. Dette er også en situation, som den Europæiske Centralbank har måttet sande de senere år, trods ihærdig brug af Quantitative Easing. Investeringsniveauet skal op, mens opsparingsniveauet skal ned, hvilket vil hæve ligevagtsrealrenten.

Et bidrag, der overses i diskussionen af stagnation, er ydet af den keynesianske økonom Josef Steindl, hvis teorier bygger videre på principperne om den effektive efterspørgsel fra Keynes og Kalecki. Han tillægger fordelingsmæssige aspekter, magtforhold, institutionelle forhold samt økonomisk politik betydning i sin forklaring af stagnationen. I 1952 udgav han værket Maturity and Stagnation in American Capitalism, hvori han analyserede udviklingen i mellemkrigstidens USA. Bogen fik dog ikke den 
modtagelse, som Steindl selv havde håbet på (Hein 2014, 227; Dutt 2006, 340). Dette forklarer han selv senere med 1950'ernes lave arbejdsløshed og voksende levestandard - en situation, der afviger markant fra perioden, der analyseres i bogen, hvorfor interessen for bogen var meget begrænset. Han videreudviklede senere sin teori i flere omgange (fx 1979 og 1982), hvor bl.a. husholdningernes rolle bliver inddraget $\mathrm{i}$ analysen. Formålet med denne artikel er at anvende Steindls teoretiske fundament til at foretage en analyse af de danske husholdningers adfærd som en af årsagerne til stagnationen i den danske økonomi. Herefter vil den førte økonomiske politik blive diskuteret, ligesom en Steindl-inspireret løsning vil blive fremført.

I afsnit to vil en præsentation af Steindls tankegang finde sted. På baggrund af dette fundament præsenteres $i$ afsnit tre en analyse af husholdningernes adfærd op til krisen som en af årsagerne til stagnationen. I fjerde afsnit inddrages resten af den private sektor samt såvel den offentlige sektor som udlandet, inden en diskussion af mulighederne for at bekæmpe stagnationen vil finde sted i afsnit fem. I sjette afsnit vil en række konkluderende bemærkninger blive præsenteret.

\section{Steindl og Stagnation}

I 1952 udgav Steindl værket Maturity and Stagnation in American Capitalism, hvori der tilbydes en forklaring på stagnation i det kapitalistiske samfund. Med maturity henviser Steindl til en tilstand: "in which the economy and its profit function are adjusted to the high growth rates of earlier stages of capitalist development, while those high growth rates no longer obtain" (Steindl 1979, 7). I en sådan situation vil profitfunktionen således være målrettet en vækstrate, der overstiger den nuværende vækstrate. I Steindl (1952) opstår den makroøkonomiske stagnation på baggrund af markedsstrukturen på det mikroøkonomiske niveau. På et marked med fuldkommen konkurrence vil en innovation medføre en midlertidig stigning i profitten hos den innovative virksomhed, mens diffusionen af innovationen gennem lavere priser og større produktion vil reducere og fordele profitten. Innovationen fører dog samtidig til en stigning i markedsandelen for de mest innovative og produktive virksomheder, hvilket vil resultere i en bevægelse mod oligopol. I denne markedsform vil innovation (eller teknologiske fremskridt, der effektiviserer produktionen) ikke medføre et fald i priserne, da oligopolvirksomhederne kan tjene overnormal profit. Et ønske om en stigning i profitmargin (mark-up) hos disse virksomheder øger dog ikke profitten for økonomien som helhed, der bestemmes af selvsamme virksomheders investeringer (der styres af tidligere beslutninger). Derfor medfører en stigning i oligopol-virksomhedernes profit et fald i kapacitetsudnyttelsesgraden, hvilket kan få virksomheden til at reducere investeringsniveauet. Et fald i investeringsniveauet har en kontraktiv effekt på den effektive efterspørgsel og dermed den økonomiske vækst (Steindl 1979, 7). Det var på baggrund af denne ændring i den amerikanske markedsstruktur, at Steindl begrundede krisen i 1930'erne. Overgangen til store virksomheder medførte en stigning i profitmargin, hvilket undertrykte reallønnen og 
derigennem salg, kapacitetsudnyttelsesgrad og investering. Den store stigning på aktiemarkedet fortrængte midlertidig den nævnte kontraktive effekt, men med krakket i 1929 kunne krisen ikke længere holdes tilbage.

I den efterfølgende periode, var situationen ifølge Steindl imidlertid en anden:

"From this point of view it is not, in principle, difficult to understand how the pre-war conditions of under-use of resources were avoided after the last war; a very high long term rate of growth imposed by certain favourable exogenous conditions on the post-war economy made it work." (Steindl 1979, 1)

Undertrykkelsen af den iboende tendens mod stagnation skyldes i første omgang krigen og senere eksogene betingelser - våbenkapløbet og andre ekspansive finanspolitikker er eksempler på disse eksogene betingelser. På baggrund af den økonomiske udvikling i 1970'erne anvendte Steindl i 1979 igen sit fundament til at forklare den økonomiske afmatning i 1970'erne. Op gennem 1950'erne og 1960'erne havde en ekspansiv politik (herunder våbenkapløbet) været rettet mod målsætningen om en lav arbejdsløshed (fuld beskæftigelse). Denne politik havde holdt den samlede efterspørgsel på et højt niveau. I 1970'erne skete der dog en forandring:

\section{"However, in the 1970s, fear of inflation and the reduced commitment to the welfare state led to contractionary policies, which reduced aggregate demand and revealed the underlying and latent tendencies towards stag- nation along the lines of Steindl's theory." (Dutt 2006, 340)}

I artiklen The Role of Household Saving in the Modern Economy fra 1982 integrerede Steindl konsekvensen af husholdningernes adfærd, hvor faktorer, der påvirker den effektive efterspørgsel positivt på kort sigt, faktisk har den modsatte effekt på længere sigt - herunder husholdningernes låntagning. Husholdningernes store låntagning ses som "the mainstay of the large and extended boom after 1982" (Steindl 2012, 195). Den positive effekt fra låntagningen aftager dog med tiden, og den negative effekt forbundet med låntagningen (rentebetalinger og afdrag) indtræder, og en stagnation åbenbarer $\operatorname{sig}^{2}$. Linket mellem vækst og fordeling spiller således en central rolle i analysen, hvor en omfordeling mellem de husholdninger, der optager lån og de husholdninger, der har opsparing, finder sted via rentebetalinger. ${ }^{3}$ Steindl døde dog i 1993, hvilket betød, at

\footnotetext{
${ }^{2}$ Godley advarede mod en tilsvarende udvikling i den amerikanske økonomi, hvor han anså vækstraten i husholdningernes låntagning som uholdbar og som et skridt på vejen mod en krise (Godley 2000).

${ }^{3}$ En grundlæggende antagelse i analysen er, at husholdningernes opsparingsrate ikke er konstant på tværs af indkomstfordelingen. Denne antagelse er konsistent med Keynes, hvor forbrugstilbøjeligheden aftager i takt med stigninger i indkomsten. Dette er et brud på tanken bag livscyklusmodellerne (fx Modigliani \& Brumberg 1954, Friedman 1957 eller Nationalbanken 2013), hvor husholdningerne på lang sigt søger at fordele forbruget stabilt over hele livsforløbet på baggrund af livsindkomsten og formue. Det skaber en sammenhæng mellem forbrugskvoten og formuekvoten, der dog empirisk ifølge Olesen (2008) ikke har været til stede siden 1998. I disse modeller varierer opsparingsraten ikke på tværs af indkomstfordelingen, hvilket kritiseres skarpt af bl.a. Frank (1997), Van Treeck (2012) og Goda (2013).
} 
han aldrig nåede at se, hvorvidt hans forudsigelse blev korrekt. I de næste afsnit vil den nuværende økonomiske afmatning i den danske økonomi blive forklaret ud fra Steindls tankegang.

\section{Forbrugets anatomi og stagnation}

I denne del af analysen vil der kun blive set på den indenlandske efterspørgsel, hvilket fremgår af figur 2, der viser de indekserede samlede reale investeringer, det reale private forbrug og det samlede offentlige forbrug med værdien i 2007 som basisår:

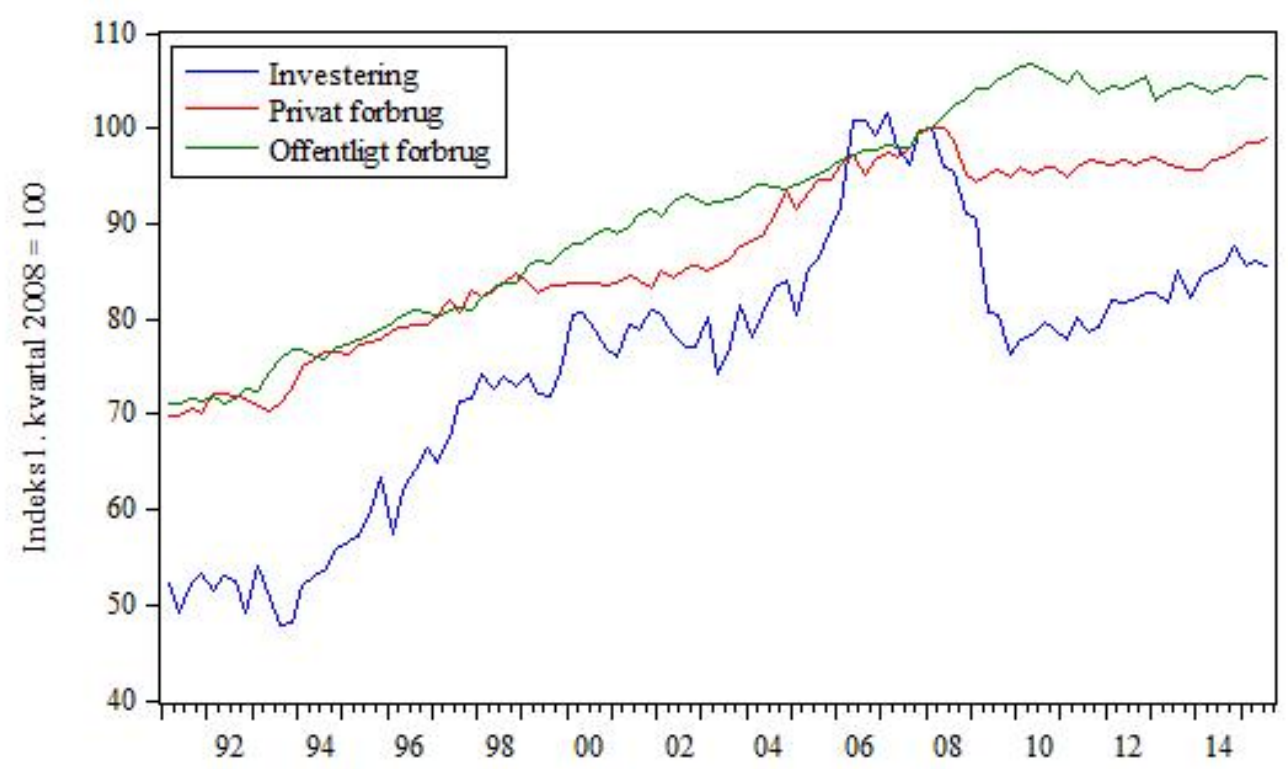

Anm: data opgjort kvartalsvist i 2010-priser og sæsonjusteret. Kilde: Danmarks statistik

Figur 2. Udviklingen i den indenlandske efterspørgsel: privat forbrug, offentligt forbrug og investeringer fra 1991-2015

Figuren viser to interessante udviklinger: For det første steg alle tre indenlandske efterspørgselskomponenter i perioden fra 1991-2007 (for det offentlige forbrugs vedkommende fortsatte stigningen indtil 2010). Dette billede bekræftes ligeledes ved at se på de enkelte komponenters bidrag til realvækst i BNP, hvor alle tre kontinuerligt bidrog positivt til realvæksten i BNP. ${ }^{4}$ For det andet ses det, at det reale private forbrug og de reale investeringer stadig er på et lavere niveau end i 2007, mens det reale offentlige forbrug er på et lavere niveau end i 2010. Så længe der udelukkende fokuseres på den inden-

\footnotetext{
${ }^{4}$ For investeringernes vedkommende var bidraget dog marginalt negativ i 1999, 2001 og 2002. Mens husholdningernes forbrug ligeledes bidrog negativt (-0,1\%) i 1999.
} 
landske efterspørgsel, kan det således fastslås, at den manglende vækst i den danske økonomi skyldes manglende vækst i alle tre efterspørgselskomponenter.

Forud for 2007 var der en lang periode med stigninger i det reale private forbrug, hvor specielt perioden fra 2003-2007 var kendetegnet ved en stigning, der oversteg den gennemsnitlige vækstrate i det reale private forbrug. Husholdningernes adfærd kan således på den reale side karakteriseres gennem et aggressivt forbrugsmønster, hvor husholdningernes opsparing ${ }^{5}$ er lavere end husholdningernes investering. Hvis der ses på den finansielle side af økonomien, ses det af nedenstående figur 3 , at husholdningerne har øget deres finansielle passiver mere end deres finansielle aktiver for at finansiere denne adfærd. Denne akkumulering af gæld har medført en stigning i raten mellem husholdningernes beholdning af gæld ${ }^{6}$ og den disponible indkomst, hvilket ses af figur 4:

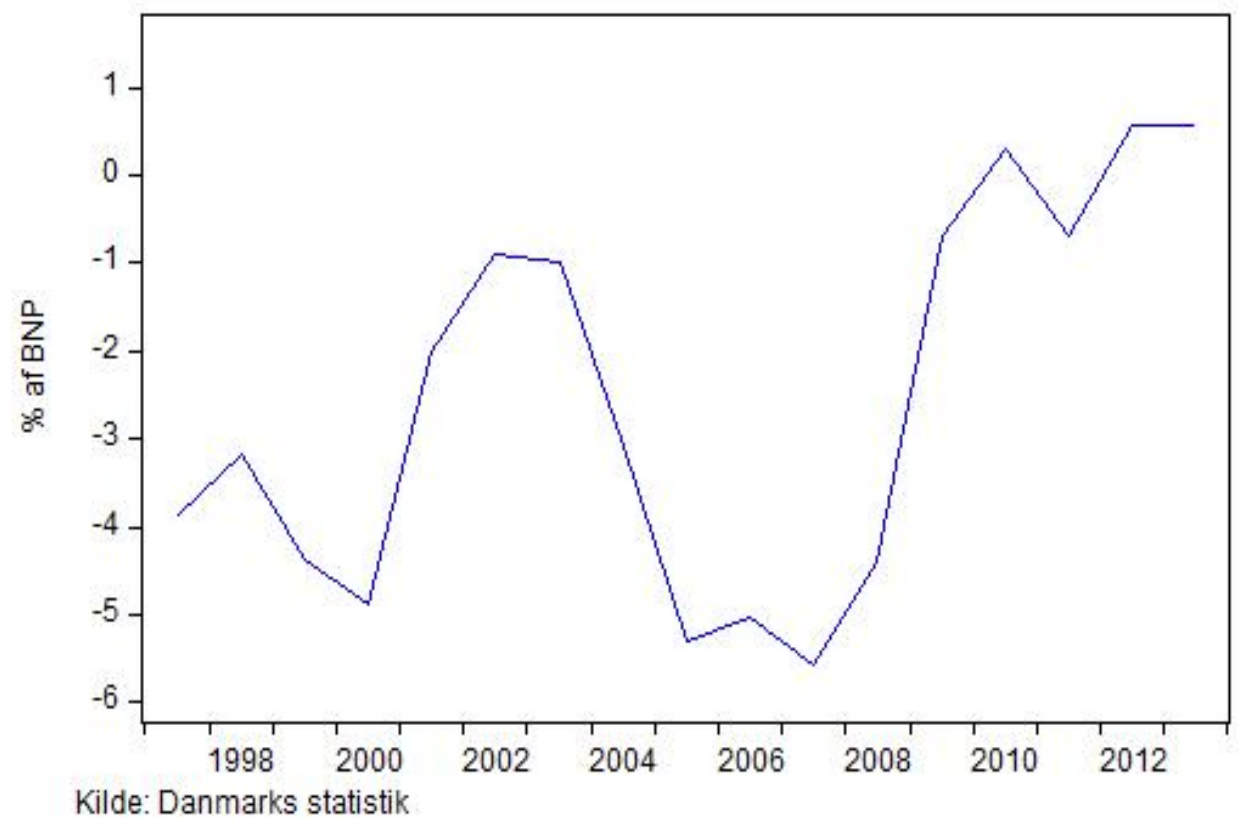

Figur 3. Husholdningernes nettofordringserhvervelse

\footnotetext{
${ }^{5}$ Husholdningernes opsparing er opgjort som den del af den disponible indkomst, som ikke er anvendt til forbrug.

${ }^{6}$ Der ses her på danskernes samlede bruttogæld, hvilket derfor også inkluderer boliglån. Der kunne sagtens argumenteres for, at disse ikke skulle medbringes i oversigten, idet disse ikke kun udgør et nettopassiv for sektoren, idet det som udgangspunkt modsvares af et aktiv i form af boligen.
} 


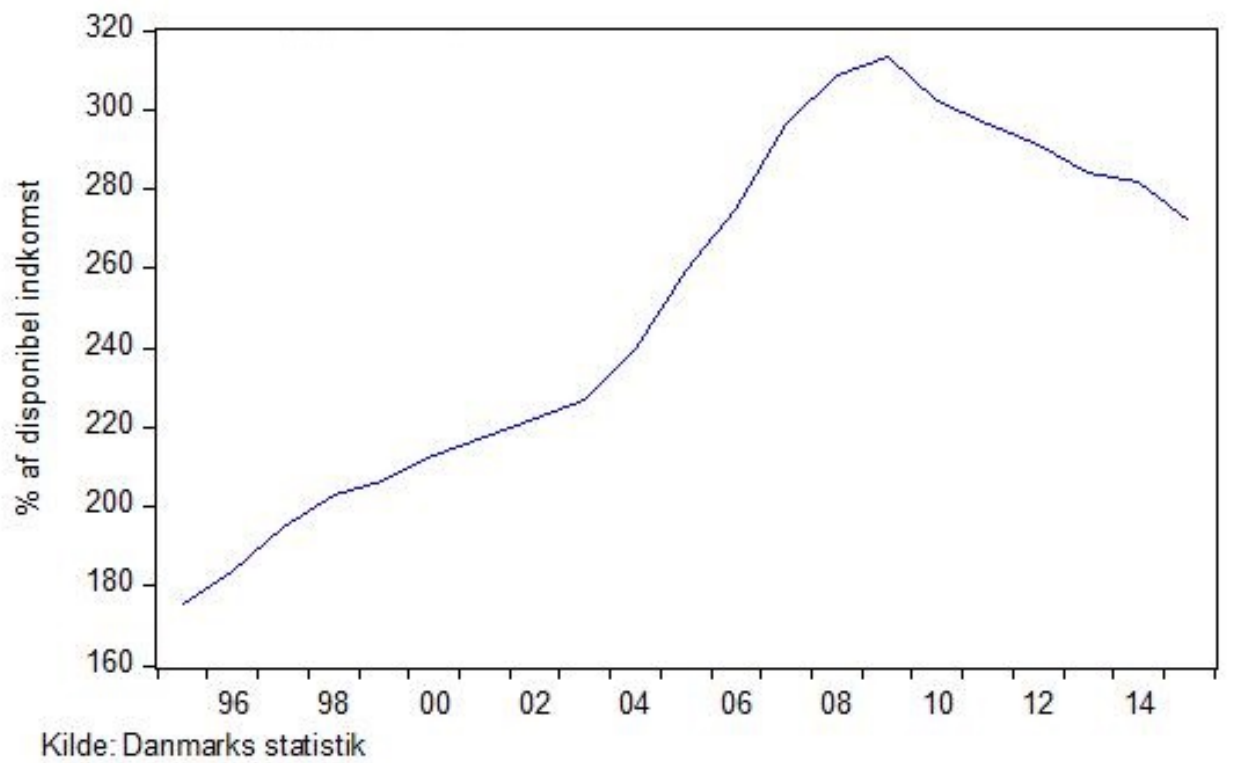

Figur 4. Husholdningernes gælds/disponible indkomst rate

De danske husholdninger har således kraftigt øget deres bruttogældsbeholdning frem mod 2009, hvorefter der sker et knæk på kurven, og gældsraten igen aftager. Fra 19952009 skete der en stigning i gælden fra at udgøre $175 \%$ af den disponible indkomst i 1995 til at udgøre $310 \%$ af den disponible indkomst i 2009. Adfærden kan forklares fra såvel udbudssiden som efterspørgselssiden: På udbudssiden kan institutionelle ændringer anvendes som forklaring på husholdningernes ændrede adfærd i perioden. Dereguleringen på de finansielle markeder og indførslen af nye lånetyper gav husholdningerne billigere og lettere adgang til kredit. Her fremstår indførslen af afdragsfrie lån i 2003 samt flexlån fra realkreditforeningerne som gode eksempler på låntyper, der gav husholdningerne nye muligheder. På efterspørgselssiden argumenterer Veblen (1899), Duesenberry (1949) og Frank (1989) alle for, at adfærden hos den enkelte påvirkes af adfærden hos andre husholdninger. Dette gøres gennem betydningen af husholdningernes relative status som en vigtig faktor bag husholdningernes adfærd. Indkomst og forbrug er bestemmende for den enkelte husholdnings opfattelse af egen relative position i forhold til andre husholdninger. Hos Frank (1989) henvises til undersøgelser i USA, hvor husholdningerne er villige til en nedgang $\mathrm{i}$ indkomst (og forbrug) målt i absolutte termer, såfremt det medfører en stigning i relative termer - altså at andre husholdningers indkomst er faldet endnu mere. I en situation som frem mod 2007 med økonomisk fremgang, store kapitalgevinster samt stor generel optimisme er de basale behov opfyldt og de sociale behov træder i karakter ${ }^{7}$ - forbrug skifter karakter til at sige noget om husholdningernes sociale identitet (og status) jf. bl.a. Poppe \& Jakobsen (2009):

\footnotetext{
${ }^{7}$ Der kan her henvises til fx Post-Keynesianske teorier, der efter inspiration af bl.a. Maslow opstiller husholdningernes behov i hierarkisk vis. (Byrialsen 2015)
} 
"Forbrug og investeringer til hovednøgler i etablering af aktørernes sociale identitet" (Poppe \& Jakobsen 2009, 164-165)

I en situation med stigende ulighed, hvor hverken indkomst eller formue fordeles ligeligt på tværs af indkomstfordelingen, vil den øverste del modtage størstedelen af den samlede stigning i indkomsten. Denne del af samfundet vil derfor kunne øge deres forbrug inden for indkomsten, mens resten af indkomstgrupperne vil opleve såvel et fald i den relative indkomst såvel som forbrug. I en sådan situation kan husholdningerne anse låntagning som et middel til at opnå et højere forbrug og dermed undgå store fald i det relative forbrug. I en undersøgelse foretaget af Finansrådet i 2007 har $40 \%$ af de adspurgte danskere optaget forbrugslån inden for de sidste to år, (Finansrådet 2007, 9). Den store stigning i indkomstuligheden i Danmark i perioden ${ }^{8}$ har således ført til en Keeping up with the Joneses-effekt hos de danske husholdninger, hvor husholdningerne har optaget stor gæld. Konsekvensen af gældsakkumuleringen er imidlertid ikke givet på forhånd: "there is no accepted wisdom about whether and how gross debt may restrain economic activity" (IMF 2012, 89).

En Steindl-inspireret analyse vil imidlertid være i stand til at undersøge denne effekt af gældstagning: På kort sigt vil en låntagning til forbrug hos husholdninger øge forbruget og dermed den samlede økonomiske aktivitet. En stigning i husholdningernes forbrug har en positiv effekt på virksomhedernes samlede kapacitetsudnyttelsesgrad og dermed virksomhedernes ønskede niveau for investering. En stigning i låntagningen medfører imidlertid en stigning i husholdningernes gæld, hvorfor der ligeledes skal tages højde for effekterne af dette. En stigning i husholdningernes gældsbeholdning har en negativ effekt på den samlede økonomiske aktivitet, der afhænger af størrelsen på opsparingsraten, låntagningen og renten. Dynamikken kan forklares ved, at rentebetalingerne medfører en omfordeling mellem låntager og långiver, hvor rentebetalingens størrelse afhænger af både renten og gældens størrelse. Da opsparingsraten kan observeres til at stige i takt med indkomsten, bevirker dette, at omfordelingen sker mod en del af befolkningen, der har en lavere forbrugskvote. ${ }^{9}$ Husholdningernes låntagning, der indledningsvist har en positiv effekt på den samlede efterspørgsel, bærer således spiren til sin egen undergang igennem en stigning i husholdningernes gældsbeholdning. Stigningen i denne gældsbeholdning skaber en kontraktiv effekt på den samlede efterspørgsel $^{10}$, som med tiden kan overstige den ekspansive effekt ved låntagningen, som beskrevet af Steindl (2012):

\footnotetext{
${ }^{8}$ Gini-koefficienten i Danmark voksede fra 24 i 2000 til 28 i 2008 (Danmarks Statistik). I OECD (2011, 1) gøres desuden opmærksom på, at uligheden i Danmark (samt Sverige og Tyskland) faktisk er vokset mere end i noget andet land.

${ }^{9}$ Som nævnt i note 2 aftager forbrugstilbøjeligheden med stigninger i indkomsten.

${ }^{10}$ Her kan analyseres yderligere uddybes med den eventuelle påvirkning en lavere privat forbrugsefterspørgsel kan have på virksomhedernes ønskede investering. I en Steindl-inspireret model antages det ønskede niveau for investeringerne at afhænge af bl.a. udnyttelsesgraden af kapitalapparatet. Når udnyttelsesgraden stiger, vil virksomhederne ønske at foretage nye investeringer. I teksten fremføres således en negativ sammenhæng mellem en stigning i husholdningernes gælds-kapital-rate og den samlede efterspørgsel via forbrugskanalen. Denne kontraktive effekt på den samlede efterspørgsel vil imidlertid med-
} 


\begin{abstract}
"When effective demand is created by one means [låntagning hos husholdningerne] or another, the beneficial effects on employment in general will show themselves fairly soon... After a time, however, there appear effects which go in the opposite direction." Steindl $(2012,189)$
\end{abstract}

For husholdningernes vedvarende låntagning er problemet, at den akkumulerede gæld ikke modsvares af aktiver i den producerende sektor. ${ }^{11}$ Rentebetaling betales derfor ikke ud fra et overskud, men i stedet ud fra den disponible indkomst, som forklaret ovenfor. Dette mindsker den disponible indkomst og kan derfor i værste fald medføre yderligere akkumulering af gæld for at oprette et ønsket forbrugsniveau. Spørgsmålet er naturligvis, om en sådan udvikling kan være holdbar over en længere periode? Som nævnt ovenfor, så er der i en gældsdrevet vækst en iboende kontraktion i form af rentebetalingerne (samt nedbringelse af gæld) fra de husholdninger, der har optaget gælden og dermed været drivkræfter i væksten. Der findes således et modsatrettet forhold: Den ekspansive effekt af selve låntagningen og omfordelingseffekten som følge af rentebetalinger for den stigende gældsbeholdning, der omfordeler indkomst fra husholdninger med høj forbrugskvote til husholdninger med lavere forbrugskvoter, hvilket sænker virksomhedernes samlede kapacitetsudnyttelsesgrad og dermed efterspørgslen efter investering og den samlede efterspørgsel i økonomien. ${ }^{12}$ Som illustreret $\mathrm{i}$ figur 3 og figur 4 har husholdningerne ikke længere negativ nettofordringserhvervelse, men sænker i stedet deres gælds-rater. Denne udvikling kombineret med et fald i virksomhedernes ønskede niveau for investeringer, skaber således grobunden for et opsparingsoverskud i den private sektor.

\title{
Stagnationen i Danmark
}

På baggrund af ovenstående kan der argumenteres for, at vækstraterne i den danske økonomi forud for den økonomiske krise ikke kunne have været opretholdt uden husholdningernes gældsakkumulering. Overordnet set kan det siges, at ud fra en Steindlinspireret forklaring, så skyldes stagnationen:

"Stagnation is thus mainly caused by those factors slowing down sustainable demand growth - i.e., demand growth that is not driven by everrising debt-income ratios of any macroeconomic sector." Hein $(2015,28)$

\footnotetext{
føre et fald i virksomhedernes kapacitetsudnyttelsesgrad, hvilket har en negativ effekt på investeringerne, hvilket yderligere forstærker den kontraktive effekt på økonomiens samlede efterspørgsel.

${ }^{11}$ Der ses i denne forklaring bort fra boliglån, idet disse faktisk modsvares af et fysisk aktiv $i$ form af boliger.

${ }^{12}$ Som påpeget flere steder er husholdningernes adfærd ikke den eneste årsag til stagnationen. Det anvendte citat fra Steindl $(2012,189)$ peger i retningen af, at husholdningernes låntagning kun er et specialtilfælde af flere muligheder for at kompensere for manglende investeringsmuligheder $\mathrm{i}$ den produktive sektor.
} 
I nærværende analyse er argumentet derfor, at husholdningernes låntagning og den ever-rising gælds-/indkomstrate er en af årsagerne, der forårsager en slowing down sustainable demand growth. I henhold til ovenstående forstærkes den negative effekt af husholdningernes låntagning af et fald i investeringerne. Netop et kraftigt fald i investeringerne ses ligeledes at være tilfældet $\mathrm{i}$ figur 2 . Det store fald $\mathrm{i}$ investeringerne kombineret med den generelle tilbageholdenhed $\mathrm{i}$ den private sektor har resulteret $\mathrm{i}$, at der $\mathrm{i}$ Danmark er en situation, hvor opsparingen i den private sektor overstiger investeringerne. Denne udvikling skaber således grobunden for en stagnation, medmindre den offentlige sektor griber ind. Sammenhængen mellem væksten i økonomien, den private sektor og den offentlige sektor kan illustreres gennem tre-sektor-balancen; Opsparingsoverskud i den private sektor er lig overskuddet på betalingsbalancens løbende poster minus opsparingsoverskuddet $\mathrm{i}$ den offentlige sektor. Figur 5 viser netop tre-sektor-balancen for den danske økonomi i omtalte periode:

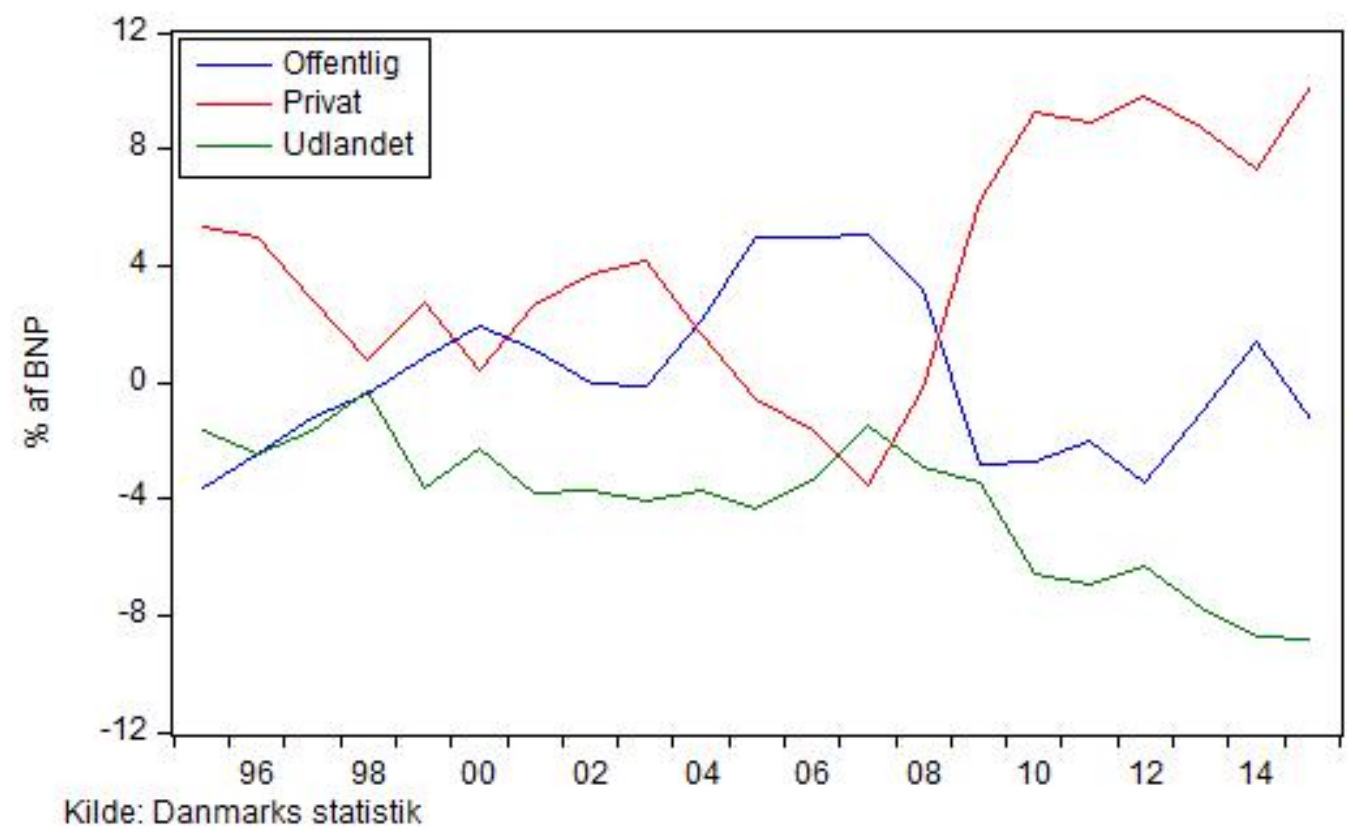

Figur 5. Tre-sektor-balancen for Danmark i 1995-2013

I figuren illustreres de finansielle balancer for de tre sektorer i forhold til BNP: den private sektor (rød linje), den offentlige sektor (blå linje) og udlandet (grøn linje). ${ }^{13}$ Summen for de tre balancer vil, som det fremgår af figuren, summere til 0 . For den private sektors vedkommende viser grafen opsparingsoverskud i sektoren siden 2009. Problemet for den danske økonomi er derfor, at den private sektor har et stort opsparingsover-

\footnotetext{
${ }^{13}$ Da denne analyse indtil videre udelukkende har set på den indenlandske efterspørgsel, har samhandel med udlandet været ignoreret. Denne afgrænsning vil nu blive opblødet, hvorfor handel med udlandet sammen med den førte valutakurspolitik - vil spille en rolle i diskussionen af Danmarks muligheder for at komme fri af stagnationen.
} 
skud, hvilket modsvares af et opsparingsunderskud i den offentlige sektor og overskud på betalingsbalancens løbende poster. Den offentlige sektor er imidlertid underlagt strenge krav for budgetunderskud, hvilket åbner op for spørgsmålet om, hvad Danmark kan gøre for at bekæmpe stagnationen?

Kan økonomisk politik bekæmpe stagnationen?

Det er i det foregående påpeget, hvorledes husholdningernes låntagning i første omgang har holdt stagnationen på afstand, men efterfølgende med krisens udbrud nu besværliggør vækst i den danske økonomi. Kombineret med et lavere investeringsniveau og lav nettoeksport bliver Danmark holdt fast i en stagnation. De private virksomheder konsoliderer sig, ligesom husholdningerne søger at nedbringe deres gæld. Den private sektor har således, trods lavt renteniveau, udviklet et stort opsparingsoverskud. Steindl beskriver den særlige udfordring dette kan have på følgende måde:

"This policy of stagnation is likely to continue, since governments are preoccupied with inflation and the public debt. Budget deficits can only disappear if private investment soars again. This is unlikely in view of excess capacity, which would only disappear if there were fiscal expansion”. (Steindl 1979, 9)

Steindl taler således direkte om en stagnationspolitik, der opstår som følge af privat tilbageholdenhed og fokus på overholdelse af de offentlige budgetter. Hein fremfører som modsvar til dette en "Steindl anti-stagnationspolitik" (Hein 2015, 28-29). Som følge af denne politik skal det offentlige forbrug øges ${ }^{14}$, hvilket skal forbedre arbejdsbetingelserne for privat investering og privat forbrug. Den offentlige sektor skal ligeledes øge sine investeringer med særlig fokus på infrastruktur, teknologi, uddannelse og forskning og udvikling. I stedet for at rette fokus mod overholdelse af det offentlige budget bør politikkerne have en målsætning om fuld beskæftigelse. Dette vil øge arbejdernes forhandlingsstyrke og dermed øge lønandelen af den samlede indkomst på bekostning af profitandelen. Dette kombineret med øget regulering af den finansielle sektor kan svække indkomstkravene hos profitmodtagere og aktionærer. Denne omfordeling af indkomst vil mindske husholdningernes usikkerhed og dermed mindske forsigtighedsopsparingen, hvilket vil medføre en sænkning af husholdningernes samlede opsparingstilbøjelighed. Slutteligt skal der ske en forbedring af den internationale koordinering af økonomisk- og pengepolitik med henblik på at undgå betalingsbalanceubalancer, beggar-thy-neighbor-politik og stigende gældsbeholdning i udenlandsk valuta. En politik, der tager højde for ovenstående tiltag, vil således ifølge Steindl (og Hein) kunne bekæmpe stagnationen. På baggrund af de første krav i forslaget om en vækst i det offentlige forbrug og investeringer vil den førte politik i Danmark blive diskuteret.

\footnotetext{
${ }^{14}$ Finanspolitikken skal anvendes modcyklisk, ganske som Keynes beskrev.
} 
Når den private sektor ikke er i stand til at trække Danmark ud af stagnationen, bør staten - i henhold til Steindls udsagn - træde til ved at føre en ekspansiv finanspolitik. Der er tale om en række muligheder, hvor finanspolitikken består i at sætte et større offentligt forbrug eller offentlige investeringer i gang uden at øge skatteniveauet. Det kan ske ved en skattelettelse, der lokker mere privat forbrug i gang eller beskatte den private sektors opsparingsoverskud og sætte offentlige aktiviteter i gang. Som i de fleste tilfælde viser det sig, at det økonomisk tekniske mulighedsrum er større end det politiske mulighedsrum. Det er bemærkelsesværdigt, at det reale offentlige forbrug i Danmark ikke er vokset siden 2010 jf. figur 2. Umiddelbart efter den finansielle og økonomiske krises udbrud blev der iværksat ekspansive tiltag i 2008-2009. Ligeledes begyndte de automatiske stabilisatorer at træde i funktion, hvilket er effektfuldt, idet Danmark har Europas mest kraftigt virkende stabilisatorer (Finansredegørelsen 2014, Dolls et al. 2012). Der blev dog i 2010 iværksat en kraftig opbremsning af den finanspolitiske ekspansion, idet det var udsigt til at overtræde Vækst- og Stabilitetspagtens grænse for offentligt underskud på $3 \%$ af BNP. Danmark modtog i den forbindelse en officiel advarsel fra EU, (Finansministeriet 2010). Den økonomiske politik i Danmark er således henholdsvis underkastet nogle selvpåførte regler for økonomisk politik i EU. Inden finanspolitikken underkastes en nærmere undersøgelse er det dog i relation til EU mest oplagt at starte med den danske penge- og valutakurspolitik. Danmark har siden Bretton-Woods systemets sammenbrud været med i forsøgene på at etablere fastkurssamarbejde i Europa med Tyskland som ankerland. Valutakurspolitikken blev yderligere cementeret med etablering af fastkurssamarbejdet i 1982 og senest med tilknytningen til Euro-kursen. Det indebærer, at pengepolitikken er fokuseret mod at sikre den faste valutakurs. Dette har givet haft nogle fordele i starten, men meget tyder på, at lande med fleksible valutakurser er kommet lettere gennem den aktuelle økonomiske krise i form at større økonomisk vækst (Andersen og Malchow-Møller 2015a; 2015b), hvor udviklingen i bl.a. beskæftigelsestallene for Sverige har været langt mere positive end i Danmark. Endvidere er Euro-området stagneret som afsætningsmarked for dansk eksport. Det er lande uden for Eurozonen, som har trukket den danske eksport og den smule vækst, der har været siden krisens start.

Selv om valg af valutakursregime kan betyde meget for nettoeksporten, er der ikke udsigt til, at valutakurspolitikken i Danmark ændres foreløbig. Og valget står ikke mellem fleksible valutakurser og fastkurssamarbejde, men mellem deltagelse i den fælles mønt, Euroen og så fastkurs-samarbejde. Sidstnævnte bliver ikke løst foreløbigt, idet spørgsmål skal afklares ved en folkeafstemning. Senest i 2000 stemte et flertal af befolkning imod optagelse i EURO-samarbejdet. Siden afstemningen er der løbende foretaget meningsmålinger om danskernes holdning til euroen. Disse meningsmålinger peger heller ikke i retningen af en yderligere dansk deltagelse i den fælles møntsamarbejde. ${ }^{15}$ Penge- og valutakurspolitikken er på denne måde fastlåst. Samme tendens er begyndt at gøre sig gældende for finanspolitikken. Den er efterhånden blevet mere regel-

\footnotetext{
${ }^{15}$ I en meningsmåling foretaget af Danske Bank i 2014 ville kun 17,2 \% af danskerne stemme ja til euroen, såfremt der var valg i dag. 52,3 \% ville derimod stemme nej. (Danske Bank 2014)
} 
bundet. Hvor pengepolitikken i Euroområdet er fokuseret mod at sikre lav inflation, er finanspolitikken rettet mod at sikre moderat offentlig gældssætning. I dansk sammenhæng er der i forlængelse af Finanspagten gennemført en såkaldt budgetlov, som i sit indhold er skrappere end det, der fordres med Finanspagten. Ligeledes er der fastlagt en 2020-plan som afløser for henholdsvis 2015- og 2010-planen, som alle fokuserer på langsigtet holdbarhed i de offentlige finanser. Det giver sig udslag i mål for finanspolitisk holdbarhed, strukturel balance på den offentlige saldo i 2020, årlige strukturelle underskud på højest en $1 / 2 \%$ af BNP og overholdelse af udgiftslofter (herunder i kommuner og regioner) (Finansredegørelse 2014, 313). Dette sker under indtryk af den ovenfor nævnte problematik vedrørende den henstilling, Danmark modtog i 2010 om, at det faktiske offentlige underskud ville overskride $3 \%$-reglen i Vækst- og stabilitetspagten. Dette kom herefter til at udgøre en særskilt rammebetingelse for finanspolitikken:
"Siden finanskrisen indtraf, er der ikke i noget år aktivt besluttet forøgel- ser af den fremadrettede vækstramme til offentligt forbrug af hensyn til konjunkturerne, men derimod indtraf et stort skred i forbrugsudgifterne $\mathrm{i}$ 2009-2010. Denne ikke-planlagte stigning i udgifterne er efterfølgende rullet delvist tilbage" (Finansredegørelsen 2014, 317)

Perioden efter 2010 kan i virkeligheden betragtes som en såkaldt finanspolitisk konsolidering, som skal efterleve EU-henstillingen. Dette forløber til og med 2013, hvorefter den strukturelle balance er forbedret så meget, at Danmark igen overholder de fastsatte mellemfristede saldomål. Omkring $3 / 4$ af alle offentlige udgifter er omfattet af det i Budgetloven beskrevne udgiftsloft. Undtaget fra udgiftslofterne er offentlige anlægsinvesteringer, renteudgifter på offentlig gæld og ledighedsrelaterede udgifter, dvs. dagpenge, kontanthjælp og aktivering. Dermed er der sammen med skatteinstrumenterne givet plads til, at de automatiske stabilisatorer overordnet set kan virke frit. Det er her væsentligt at notere, at de offentlige investeringer ikke har haft nogen fremtrædende rolle $\mathrm{i}$ konjunkturpolitikken fra 2008-2015. Og som netop nævnt gælder det også det øvrige offentlige forbrug, der ligger under udgiftsloftet, at det ikke har haft nogen rolle i form af en aktiv diskretionær finanspolitik. Der har alene været tale om visse skattelettelser på især marginalskatten. Selv om Danmark med sin lave gælds-/BNP-rate kunne have haft et strukturelt underskud på de offentlige budgetter på op til $1 \%$, har Folketinget besluttet, at det kun skal være en halv procent. Dette sker alene med baggrund i, at det i Finansministeriet vurderes, at dette giver en tilstrækkelig afstand til Vækst- og Stabilitetspagtens grænse på $3 \%$ i underskud af BNP. De automatiske stabilisatorer - i det omfang de er undtaget fra udgiftsloftet - får således lov til at virke.

I forhold til den præsenterede Steindl-inspireret anti-stagnationspolitik, har hverken ekspansiv penge- eller finanspolitik været anvendt med henblik på at forbedre arbejdsbetingelserne for privat investering og privat forbrug for dermed at trække Danmark fri af stagnationen. 


\section{Konklusion}

Den danske økonomi er fanget $\mathrm{i}$ en længerevarende lavkonjunktur, hvor hverken de automatiske stabilisatorer, stigende forbrugstillidsindikatorer eller en historisk lav rente har været i stand til at sætte gang i den danske økonomi. Den nuværende konjunkturudvikling kan således ikke betragtes som mekanisk, men skal i stedet analyseres anderledes.

Hansen introducerede tilbage i 1930'erne begrebet vedvarende stagnation om en situation, hvor økonomien var havnet i en tilstand med lave vækstrater. Et bidrag, der ofte overses i denne stagnationsdebat, blev ydet af Steindl. Han pegede på, at en vækst, der beror på en vedvarende stigning i gælds-/indkomst-rate hos en af de makroøkonomiske sektorer, ikke er holdbar i længden. Før eller siden vil den negative effekt ved gældsakkumuleringen overstige den positive effekt ved låntagningen, hvorfor økonomien vil opleve en vækstrate lavere end normalt. For at undersøge dette, er der i denne artikel sat fokus på det private forbrug og ikke mindst den låntagning, der kan ligge bag en stigning i det private forbrug. Husholdningernes låntagning har i henhold til Steindl i første omgang haft en positiv effekt på økonomien. Denne positive effekt vil dog med tiden aftage og en negativ effekt forbundet med låntagningen (rentebetalinger og afdrag) indtræder og resulterer i stagnation. Rentebetalingen medfører en omfordeling mellem låntager og långiver, hvor den indbyrdes forskel i forbrugskvoten også spiller en rolle for størrelsen på den negative effekt. Selve rentebetalingen betales ikke ud fra et overskud, men i stedet ud fra den disponible indkomst, hvilket i værste fald kan medføre yderligere akkumulering af gæld for at oprette et ønsket forbrugsniveau. I samme periode bidrog reale stigninger $\mathrm{i}$ såvel investeringerne som det offentlige forbrug positivt til væksten i den reale BNP, men siden 2007 er billedet vendt: fald i såvel forbrugs- som investeringstilbøjeligheden $\mathrm{i}$ den private sektor, opbremsning og ingen nævneværdig stigning i hverken offentligt forbrug eller investeringer. Danmark er i sin økonomiske politik underlagt økonomisk-politiske rammer, der sætter grænser for, hvor omfattende indgreb, der kan laves i forhold til stagnationen. Pengepolitikken er reserveret til at tage sig af fastkurspolitikken, og finanspolitikken er underkastet Finanspagtens krav. Sidstnævnte kan kun ændres, hvis det økonomisk-politiske paradigme ændres blandt Eurolandene i retning af at give mere plads til en mere aktiv, men koordineret finanspolitik.

På baggrund af nærværende analyse kan der derfor at kunne argumenteres for, at en Steindl-inspireret analyse med fokus på den danske husholdningers låntagning er i stand til at forklare årsager til stagnation i Danmark: En lav efterspørgsel som følge af de negative effekter af høje gælds/indkomstrater i den private sektor og et politisk fokus på overholdelse af de offentlige budgetter og nedbringelse af den offentlige gæld. 
Litteratur

Andersen, T. and Malchow-Møller, N. (2015a). Innovations in Mortgage Finance and the Onset of the Great Recession in a Small Open Economy with a Euro Peg. Comparative Economic Studies, vol. 57, December, pp. 711-734.

Andersen, T. and Malchow-Møller, N. (2015b). Inflation Targeting and Macroeconomic Performance since the Great Recession. Oxford Economic Papers, vol. 67(3), pp. 598-613.

Bernanke, B. (2015). Why are interest rates so low, part 3: The Global Savings Glut. [blog]. Brookings Institution. Available at: http://www.brookings.edu/blogs/ben-bernanke/posts/2015/04/01-why-interestrates-low-global-savings-glut

Byrialsen, M. (2015). Makroøkonomisk modeller og danskernes adfcerd - en postkeynesiansk analyse, Aalborg Universitetsforlag, Aalborg Universitet.

Cynamon, B. Z. and Fazzari, S. (2013). The End of a Consumer Age. In: B. Cynamon, S. Fazzari and M. Setterfield, M., ed., After the Great Recession: Keynesian Perspectives on Prospects for Recovery and Growth. Cambridge: Cambridge University Press.

Danmarks Nationalbank. (2013). Kvartalsoversigt, 2. Kvartal, del 2. København: Danmarks Nationalbank .

Danske Bank. (2014). Danske Banks ØMU-måling - "Nej”-sidens forspring skrumpet en smule, Macro Research, Investeringsanalyse - Generelle markedsforhold, 24. marts 2014, København: Danske Bank.

Dolls, M., Fuest, C. and Peichl, A. (2012). Automatic stabilization and discretionary fiscal policy in the financial crisis'. IZA Journal of Labor Policy, vol. 1(4), pp. $1-19$.

Duesenberry, J. S. (1967 [1949]). Income, Saving and the Theory of Consumer Behaviors, 1st Published as Galaxy Book 1967, Oxford, Oxford University Press.

Dutt, A. (2006). Maturity, Stagnation and Consumer debt: A Steindlian Approach. Metroeconomica, vol. 57(3), pp. 339-364.

Finansministeriet. (2010). Aftale mellem regeringen og Dansk Folkeparti om genopretning af dansk økonomi. København: Finansministeriet.

Finansredegørelsen. (2014): Finansredegørelsen (2014), København: Finansministeriet.

Finansrådet. (2007). Lån til forbrug. [pdf] Available at: http://www.finansraadet.dk/Media/dokumenter/politik/analyser/lån_til_forbrug_ 21-12-2007\%20(pdf).pdf .

Frank, R. (1989). Frames of Reference and the Quality of Life. The American Economic Review, vol. 79(2), pp. 80-85.

Frank, R. (1997). The Frame of Reference as a Public Good', Economical Journal, vol. 107, pp. 1832-47.

Frank, R., Levine, A. and Dijk, O. (2010). Expenditure Cascades, Working Paper 2010. 
Goda, T. (2013). The role of Income Inequality in Crisis Theories and in the Subprime Crisis, Working Paper 2013, PKSG.

Godley, W. (2000). Seven Unsustainable Processes:Medium-Term Prospects and Policies for the United States and the World, Strategic Analysis. Annandale-OnHudson, N.Y.: The Levy Economics Institute of Bard College

Hansen, A. (1939). Economic Progress and Declining Population Growth. The American Economic Review, vol. 29(1), pp. 1-15.

Hein, E. (2014). Distribution and Growth after Keynes - A Post-Keynesian Guide, Cheltenham, Edward Elgar Publishing.

Hein, E. (2015). Secular Stagnation or Stagnation Policy? Steindl after Summers, Working Paper No. 846, Annandale-On-Hudson, N.Y.:Levy Institute of Bard College, Oktober 2015

IMF. (2012). Dealing with Household Debt, Chapter 3 I World Economic Outlook: Growth Resuming, Dangers Remain, Washington DC, International Monetary Fund.

Keynes, J. M. (1997 [1936]). The General Theory of Employment, Interest and Money, London, Prometheus Books.

Krugman, P. (2013). Secular Stagnation, Coalmines, Bubbles, and Larry Summers. [Blog]. Available at: http://krugman.blogs.nytimes.com/2013/11/16/secularstagnation-coalmines-bubbles-and-larry-summers/

OECD. (2011). Divided We Stand - Why Inequality Keeps Rising. [Pdf].

Available at: http://www.oecd-ilibrary.org/social-issues-migration-health/thecauses-of-growing-inequalities-in-oecd-countries_9789264119536-en

Olesen, J. (2008). En forbrugsrelation for husholdningerne, København: Danmarks Nationalbank Working Paper 2008:51

Poppe, C. and Jakobsen, T. (2009). Lånefest? Betydningen af kreditfinansieret forbrug blandt udvalgte grupper $i$ den danske middelklasse, Center for kreditret og kapitalmarkedsret, Handelshøjskolen i København: Thomson Reuters 2009.

Steindl, J. (1952). The Maturity and Stagnation in American Capitalism. Oxford, Basil: Blackwell.

Steindl, J. (1979). Stagnation Theory and Stagnation Policy. Cambridge Journal of Economics, vol. 3, pp. 1-14

Steindl, J. (1982). The Role of Household Saving in the Modern Economy. Banca Nazionale del Lavoro Quarterly Review, vol. 140, pp. 69-88.

Steindl, J. (2012). Reflections on the Present State of Economics. PSL Quarterly Review, vol. 65(261), pp. 199-212.

Syll, L. (2015). The Bernanke-Summers Imbroglio. [Blog]. Available at: https://larspsyll.wordpress.com/2015/04/10/the-bernanke-summers-imbroglio/

Van Treeck, T. (2012). Did Inequality Cause the US Financial Crisis?, Working Paper 2012, Düsseldorf, IMK.

Veblen, T. (2007 [1899]). The Theory of the Leisure Class, Oxford, Oxford University Press. 